\title{
FORMULA GLORIFIKASI PEMIMPIN DALAM HIKAYAT BANJAR
}

\author{
Leader's Glorification Formula in Hikayat Banjar
}

\author{
Diyah Prilly Upartini \\ Universitas Gadjah Mada \\ prillyupartini@mail.ugm.ac.id
}

\begin{abstract}
Abstrak
Makalah ini berusaha menjelaskan formula-formula yang digunakan di dalam Hikayat Banjar (HB), khususnya formula untuk mengglorifikasikan pemimpin yang dikisahkan di dalamnya. Dalam penciptaan teks $H B$, narator tidak terlepas dari formula-formula sebagai gawai untuk menata sistem kebahasaan dengan gaya-gaya retoris tertentu. Penanganan data dilakukan melalui dua tahapan, tahap pengumpulan data dan analisis data. Data-data yang dibutuhkan adalah data-data mengenai tokoh pemimpin di dalam $H B$. Setelah itu, data tersebut dianalisis dengan menggunakan metode struktural dan dilanjutkan dengan menggunakan metode formula kelisanan. Hasil analisis menunjukkan elemen-elemen yang berkaitan dengan raja atau pemimpin dikisahkan dengan sarana retorika seperti enumerasi, paralelisme, dan repetisi, baik repetisi dalam jajaran kata, frase, klausa hingga repetisi dalam bentuk wacana. Penggunaan sarana retorika tersebut bertujuan untuk menekankan betapa dominan dan istimewanya raja yang digambarkan di dalam teks $H B$. Formula juga digunakan sebagai teknik pengembangan cerita dengan menggunakan perulangan adegan yang siap pakai.
\end{abstract}

Kata-kata kunci: hikayat, formula, sarana retorika, glorifikasi pemimpin, Hikayat Banjar

\begin{abstract}
This paper tried to explain about formulas used in Hikayat Banjar (HB), specially formula for glorified leaders in it. In the creation of $H B$ text the narrator can not escape from formulas as devices to organize linguistic systems with certain rhetorical styles. Data handling is done through two steps, the first step is data collection and the second step is data analysis. The data needed is data about the leader figures in HB. After that, the data is analyzed using the structural method and continued using the oral formula method. The results of the study show the elements related to the king or leader narrated using rhetorical styles such as enumeration, parallelism, and repetition, repetition in words, phrases, clauses, and discourses form. The application of rethorical styles is for emphasizes about how dominati and special is the king described in the HB text. Formula is also used as a story development technique by using repetitive scenes that are ready to use.
\end{abstract}

Keywords: hikayat, formulas, rhetoric devices, leader glorification, Hikayat Banjar

How to Cite: Upartini, Diyah Prilly. (2020). Formula Glorifikasi Pemimpin dalam Hikayat Banjar. Jentera: Jurnal Kajian Sastra, 9(2), 147-171. doi: https://doi.org/10.26499/jentera.v9i2.2829 


\section{PENDAHULUAN}

Kesultanan Banjar merupakan salah satu pusat dari tiga kerajaan Melayu di Kalimantan selain Kerajaan Kutai dan Kesultanan Pontianak. Seperti halnya kerajaan Melayu di Sumatera dan Semenanjung Melayu, tradisi menulis juga berkembang pesat di Kesultanan Banjar. Banyak naskah Melayu yang ditemukan di Banjarmasin baik yang berbentuk syair, prosa, maupun sastra kitab. Salah satu karya sastra klasik yang menjadi perhatian sarjana serta paling penting mengenai Kesultanan Banjar adalah Hikayat Banjar (HB) (Braginsky, 1998:263, 339; Mu'jizah, 2004: 159—160; Ras, 1968:1, 628—629).

$H B$ merupakan salah satu karya sastra klasik yang berasal dari Kalimantan yang menceritakan tradisi historis tentang kerajaan Melayu yang pernah ada di Kalimantan bagian tenggara hingga tahun 1860. $H B$ menceritakan asal mula terbentuknya Kerajaan Nagara Dipa yang didirikan oleh Empu Jatmika, seorang pedagang yang berasal dari Keling, suatu wilayah di Kediri pada masa Majapahit. Selama beberapa masa, Empu Jatmika memimpin Negara Dipa dan menaklukkan kerajaan-kerajaan sekitarnya yang dikuasai oleh suku bangsa Maanyan, Ngaju, Lawangan, dan Dusun serta penduduk Melayu yang tinggal di wilayah pesisir. Kerajaan tersebut kemudian menjadi salah satu kerajaan besar di Kalimantan (Ras, 1968: 230-250). Pada masa pemerintahan Empu Jatmika dan Lambu Mangkurat, Kerajaan Nagara Dipa tidak memiliki raja resmi disebabkan oleh suatu mitos yang dipercaya bahwa seseorang yang bukan keturunan raja tidak boleh menjadi raja. Masa ini berakhir hingga Puteri Junjung Buih bersuami Raden Putra—seorang pangeran Majapahit—dan menjadi ratu dan raja pertama di Kerajaan Nagara Dipa. Nagara Dipa terus dipimpin oleh anak cucu Puteri Junjung Buih dan Raden Putra, hingga pada pemerintahan Raden Sekar Sungsang pusat kerajaan berpindah tempat dan menjadi masa akhir Nagara Dipa. Berakhirnya Nagara Dipa diiringi dengan kemunculan Kerajaan Nagara Daha, cikal bakal Kesultanan Banjar. $H B$ berakhir dengan kemelut politik yang terjadi di Kesultanan Banjar mengenai perebutan kekuasaan pada tahun 1663 (Ras, 1968).

Menurut Ras (1968:7), HB disusun ke dalam sebuah tipe sastra Melayu yang berbeda dengan tipe standar sastra Melayu Riau-Johor pada umumnya. Hal ini menjadi bukti bahwa $H B$ merupakan salah satu naskah kanon Kalimantan yang diciptakan dan ditulis oleh penulis yang berasal dari Kesultanan Banjar itu sendiri. Hal ini menjadikan $H B$ sebagai salah satu karya sastra melayu klasik yang digolongkan ke dalam korpus sastra sejarah. Fakta-fakta yang ada di dalam $H B$ bisa dikaitkan pada realita yang ada seperti wilayah geografi dan tokoh 
historis yang disebutkan di dalam $H B$. Naskah-naskah yang digolongkan ke dalam korpus sastra sejarah ini bisa dipakai sebagai sumber sejarah apabila telah disahkan dengan membandingkannya dengan catatan-catatan orang Portugis, Belanda, atau Inggris (Djajadiningrat, 1965:77; Fang, 2011:435).

Menurut Ras (Ras, 1968:VII, 1-4; Hermawan, 2005:115; Noor, 2016: 15-33), sebagai karya sejarah yang cukup penting, $H B$ berulang kali dijadikan sebagai sumber dalam penulisan kesejarahan Kesultanan Banjar baik oleh sarjana mancanegara maupun oleh sejarawan dalam negeri. Ras berpendapat bahwa naskah ini sangat jarang untuk dipertimbangkan ke dalam genre sastra yang mungkin memiliki hal penting lain selain alasan politik-historis. Untuk itulah, Ras kemudian melakukan kajian aspek filologi dan menerapkan analisis tekstual terhadap $H B$ dengan tujuan menyajikan teks dan terjemahan yang handal untuk dapat dimanfaatkan pada kajian-kajian mengenai $H B$ yang berikutnya.

Dalam penelitiannya, Ras (1968: 20-80) menemukan bahwa terdapat dua versi $H B$ yang kemudian disebutnya sebagai Resensi I dan Resensi II. Keparalelan isi kedua teks tersebut hanya terdapat pada beberapa bagian dan episode-episode tersebut tidak memiliki besaran porsi yang sama pada masing-masing isinya. Ras berpendapat bahwa Resensi II merupakan teks yang lebih tua yang awalnya merupakan teater wayang yang berkembang di luar keraton, di tengah masyarakat Hindu. Beberapa narasi yang terdapat pada Resensi II menunjukkan peristiwa-peristiwa lama yang memiliki hubungan dengan kejadian-kejadian yang lebih baru. Hal ini mengindikasikan bahwa sebagian isinya berasal dari memori populer dan bukanlah bagian dari teks asli. Hal ini berbeda dengan Resensi I yang merupakan versi yang telah diubah dan disusun pada masa Kesultanan Banjar yang secara definitif telah memeluk agama Islam dan diduga ditulis serta diciptakan di dalam istana. Berbeda dari penceritaan Resensi II yang bertele-tele, Resensi I lebih ringkas dan menciptakan kesan sebagai bentuk adaptasi singkat dari suatu cerita yang lebih panjang dan lebih komprehensif yang kemungkinan besar memiliki kesamaan dengan Resensi II. Ras menyatakan bahwa teks $H B$ Resensi II mungkin saja merupakan sebuah proto dari $H B$ Resensi I. Transformasi yang terjadi pada teks Resensi I ini terlihat pada deskripsi organisasi pemerintahan dan pengadilan, cara berperilaku yang benar, adat berpakaian, upacara dan pernyataan yang berkaitan dengan simbol-simbol status tokoh dari tingkatan sosial yang ditujukan untuk memosisikan diri mereka sendiri pada acara-acara resmi yang ditegaskan berkali-kali dan panjang lebar. 
Penelitian ini berangkat dari pernyataan Ras (1968: VII) mengenai kurangnya kajian Hikayat Banjar $(H B)$ dalam hal fungsi keberadaannya dalam memenuhi fungsinya di dalam masyarakat tempat $H B$ tercipta. Oleh karena itu, penelitian ini akan mengkaji jejak tradisi lisan masyarakat Banjar di dalam $H B$. Hal ini berkaitan dengan tradisi lisan yang telah ada sejak dulu dan masih berkembang hingga saat ini. Menurut Bondan (Bondan, 1953: 112118) seni suara dalam kesenian Banjar datangnya dari dua macam suara, yakni suara manusia dan suara bunyi-bunyian yang ditiup, dipukul, dan digosok. Tradisi lisan Banjar yang kemudian menjadi kesenian yang diperhatikan oleh pihak keraton sejak abad 17 berbentuk lagu-laguan yang dinyanyikan. Kesenian dengan lagu-lagu tersebut antara lain dundam, lamut, syair, dan pantun belagu. Menurut Bondan, dundam merupakan cerita, kisah, syair, atau pantun yang dinyanyikan dengan diiringi tabuhan tekna atau terbang besar. Dundam biasanya dibawakan ketika upacara perkawinan dan perhelatan lain seperti beranak dan bersunat. Hingga saat ini, seni dengan tabuhan terbang besar masih lazim digunakan di beberapa daerah di Kalimantan Selatan dan dikenal dengan nama baayun maulud setelah proses islamisasi terjadi di wilayah Kalimantan bagian tenggara. Selain itu, ada pula kesenian bercerita lain dengan diiringi terbang besar yang dikenal sebagai madihin. Perbedaan baayun maulud dan madihin adalah bauyun maulud digunakan sejak akhir abad 16 dan merupakan wahana dakwah Islam dengan syair-syair yang mendapat pengaruh bahasa Persia dan Arab, sedangkan madihin meskipun sama-sama digunakan sebagai sarana dakwah Islam, namun menjadi media hiburan yang diselingi pantun humor sekaligus mengandung kritik sosial serta nasihat (Noor, 2016: 381—393).

Dengan melihat peran penting tradisi lisan di masyarakat Banjar yang terus berlangsung hingga saat ini, belum adanya penelitian mengenai jejak tradisi lisan dalam $H B$ yang merupakan karya sastra klasik Banjar menjadi celah yang harus diisi. Karya sastra klasik-selain jumlah naskah yang tersedia sangat kecil dan memiliki keunikan tersendiri, serta ditulis dengan tangan yang khas — ditulis dalam bahasa atau idiom yang tidak dikenal dan membuat penerimaannya di kalangan masyarakat relatif cukup kecil. Hal ini dikarenakan masyarakat umum kesulitan untuk mengikuti alur cerita, menangkap amanat, dan menikmati manfaat sastranya ( Robson, 1994:11; Ras, 1968: 78-79). Salah satu tugas filolog, menurut Robson (1994:12) adalah membuat karya sastra klasik terbaca atau dimengerti sehingga naskah harus disajikan dan ditafsirkan dengan penjelasan yang ekstensif. $H B$ telah disunting dan disajikan sehingga mudah terbaca oleh JJ Ras, namun karya sastra memiliki banyak 
penafsiran dan tidak bersifat universal dengan makna yang tetap, serta terbuka pada semua pembaca dalam periode manapun. Dengan demikian, untuk menafsirkan suatu karya diperlukan strategi tekstual yang berlaku pada periode si pembaca untuk memberikan reaksi tertentu sebagai proses penerimaan karya sastra tersebut (Jauss, 1982: 12—19).

Sweeney (1987:1) berpendapat bahwa kebiasaan lisan bertahan dalam komposisi tulisan setua budaya naskah itu sendiri. Karangan-karangan sastra lisan dan pergelaran teater kaya dengan motif-motif dan alur-alur cerita baru yang kemudian motif-motif dan alur-alur cerita tersebut menyentuh ke pusat-pusat dunia aksara/tulisan yaitu istana-istana dan balai pendidikan. Di sinilah motif-motif dan alur-alur cerita itu ditulis, diolah, dan disempurnakan (Braginsky, 1998:60). Abdullah (1991:3) mengatakan bahwa dalam teks versi tertua, terdapat banyak sekali perulangan deskripsi dalam berbagai bentuk dengan cara mengulang larik-larik yang hampir selalu sama. Imran Teuku Abdullah menemukan corak-corak seperti ini di dalam Hikayat Meukuta Alam. Corak tersebut khas dan memperlihatkan kedekatannya dengan ciriciri puisi lisan di Aceh. $H B$ - sebagai karya sastra yang ditulis dan berkembang di tengah masyarakat yang kaya dengan tradisi lisan-memiliki kemungkinan besar merekam jejakjejak sastra lisan seperti apa yang terdapat di dalam Hikayat Meukuta Alam.

\section{LANDASAN TEORI}

Untuk mencapai tujuan penelitian dari permasalahan yang telah dikemukakan, diperlukan seperangkat proposisi untuk memberikan pola bagi interpretasi data yang disebut dengan landasan teori (Faruk, 2014:20-21). Penelitian ini dilakukan dengan menggabungkan beberapa teori pendekatan yang dipandang mampu merangkum semua permasalahan serta menjelaskan mengapa hal itu terjadi.

\subsection{Kelisanan dan Keberaksaraan}

Tulisan merupakan peralihan bahasa yang sebelumnya dilisankan kemudian menjadi suatu sistem lambang visual. Dalam perkembangannya, sastra merupakan paduan antara orality dan literacy. Dalam sastra kuno nusantara, baik sastra Jawa maupun sastra Melayu, sastra ditulis untuk dibacakan dan didengarkan bersama. Naskah tulisan kemudian ditulis dan diturunkan. Akan tetapi, budaya naskah itu menunjukkan bahwa kelisanan tetap dominan dalam penurunan naskah. Naskah diturunkan dengan menyusun kembali teks dan menyesuaikan dengan kebutuhan. Dalam tradisi naskah nusantara, teks adalah milik bersama, 
bebas untuk dimanipulasi, dicocokkan, diciptakan kembali, sesuai dengan keperluan dan kemampuan para penurun/penyalin dan dengan minat pendengar dan penontonnya (Teeuw, 1994: 177-178).

Dalam budaya sastra Melayu Islam, batas antara tradisi lisan dan tulisan seringkali menjadi kabur. Hal ini disebabkan oleh karangan-karangan tertentu dari tradisi yang satu masuk ke dalam tradisi yang lain (Braginsky, 1998:46). Salah satu contoh ialah HB yang merupakan rekonstruksi dari mitos tentang asal usul alam semesta dan manusia pada budaya Dayak Ngaju di Kalimantan bagian tenggara yang diperlengkap dengan isi baru. $H B$ berada di bawah pengaruh konsepsi Hindu-Budha tentang mata rantai kelahiran yang tidak berujung pangkal dengan menimbulkan kisah tentang penitisan atau inkarnasi tokoh-tokoh dewa atau setengah dewa ke dunia. Selain itu, $H B$ juga menceritakan kisah kelahiran, kehidupan, dan perbuatan kepahlawanannya di dunia sehingga aspek-aspek tersebut terlihat dominan.

Fungsi $H B$ sebagai karya sastra masa lalu yang menyimpan informasi dan sistem nilai yang langsung relevan untuk masyarakat tempat ia muncul tidak terlepas dari pepatah dan petitih, peribahasa dan perumpamaan, bidal, tamsil, dan kata adat yang jumlahnya begitu menonjol. Untuk mengamankan dan menyimpan hikmah dan budi bahasa itu, penceritaan $H B$ - seperti halnya epos-epos masa lalu yang lainnya — dipermudah dengan bentuk ungkapan yang khas yang bersifat formulaik. Pola penghafal harus diulang secara terus menerus agar tetap bertahan. Hal ini, menurut Sweeney (via Teeuw, 1994:24), membuat sastra dalam kebudayaan lisan sangat bergantung pada penggunaan ungkapan yang cukup baku tetapi dalam bentuk yang memiliki gaya. Sehingga dapat dikatakan bahwa struktur naratif dalam suatu karya sastra yang menghadirkan beragam peristiwa naratif merepresentasikan dan memproduksi suatu makna yang di dalamnya berisi suatu wacana atau kepentingan dalam ragam-ragam tertentu. Proses ini dilakukan agar wacana nampak sebagai sesuatu yang dibutuhkan dan bukan sebagai paksaan (Setiawan, 2014: 24-25).

Formula dan ekspresi formulaik merupakan salah satu aspek dalam teori lisan yang dikemukakan oleh Milman Parry dan Albert B. Lord dalam penelitian mereka mengenai evolusi penggubahan nyanyian rakyat Yugoslavia. Formula adalah sekelompok kata yang secara teratur dimanfaatkan dalam kondisi matra yang sama untuk mengungkapkan suatu ide yang hakiki. Ekspresi formulaik merupakan larik atau setengah dari larik yang tersusun dalam pola-pola formula yang merupakan dasar dari sastra lisan. Cara membangun larik dengan 
sistem formula ini menghasilkan ciri puisi lisan yang dominannya unsur paralelisme, repetisi, sinonimi, homonimi, dan lain-lainnya (Lord, 1971: 3-4, 30 - 67; Teeuw, 1994:3). Formula adalah ide dasar dari kumpulan epitet, epos klise, dan frase-frase stereotip yang menjadi gawai mnemonik yang cocok dengan pola matriks tertentu dan membantu penyair dalam menggubahnya. Frase-frase tersebut dapat diganti atau diadaptasi dan formula berperan sebagai placeholder. Formula merupakan ide yang hakiki dari cerita dan menjadi gawai utama dalam penciptaan karya sastra lisan tradisional. Formula menjadi kaidah yang harus dikuasai oleh pencerita untuk menyampaikan informasi yang tersimpan di dalam cerita kepada pendengarnya. Pencerita membawakan ceritanya berdasar pada formula, unsur formulaik, peribahasa, petatah dan petitih, yang disebut oleh Lord sebagai stock in trade.

\subsection{Glorifikasi Pemimpin}

Menurut KBBI, glorifikasi memiliki arti 'proses, cara, perbuatan meluhurkan, memuliakan', dan sebagainya'. Kata glorifikasi merupakan padanan dari bahasa Inggris glorification yang memiliki kata asal glorify yang di dalam kamus Oxford memiliki makna (1) exalt to heavenly glory; make glorious 'memuliakan hingga keagungan surgawi: membuat agung'; (2) transform into something more splendid 'mengubah menjadi sesuatu yang lebih hebat'; (3) extol; praise, 'mendewakan: mengagungkan'; (4) seeming or pretending to be more splendid than in reality 'tampak atau berpura-pura menjadi lebih hebat daripada kenyataan'. Dari makna yang telah disebutkan, glorifikasi berasosiasi dengan keagungan, kemuliaan, atau keluhuran.

Kata pemimpin di dalam KBBI berarti 'orang yang memimpin, mengetuai atau mengepalai (rapat, perkumpulan, dan sebagainya)'. Dalam arti yang lebih luas, Fairchild (1962:174) mendefinisikan pemimpin sebagai seseorang yang memprakarsai perilaku sosial dengan mengarahkan, menyusun, atau mengontrol upaya pihak yang dipimpin. Turner (2006:331) mengatakan bahwa istilah kepemimpinan muncul sebagai sebuah bagian penting dari suatu hubungan.

Dari dua etimologi yang telah dijelaskan dapat diambil kesimpulan bahwa glorifikasi pemimpin adalah memuliakan pemimpin yang berkuasa. Menurut Sudibyo (2000:195-196) hubungan tripartit dalam wacana kekuasaan membuat kekuasaan cenderung tak terbagi dan absolut. Hal tersebut menyebabkan terjadinya pengagungan kekuasaan disertai dengan legitimasi genealogis yang biasanya menyatakan bahwa sang penguasa adalah sosok yang 
paling tepat sebagai pemegang kekuasaan karena keturunan bangsawan tinggi, pertapa, serta, memiliki karisma. Dalam hal ini, yang dimaksud ialah pemimpin yang berlaku adil, pemurah, sakti, dan membawa kejayaan. Usaha itu dilakukan agar sang pemimpin dapat diterima rakyat tempat ia berkuasa sehingga pemimpin tersebut berupaya untuk memperlihatkan keunggulannya sebagai keturunan istimewa. Fenomena kekuasaan seperti itu telah lama menjadi kanon penulisan sejarah suatu dinasti di nusantara.

Hoesein Djajadiningrat (1965:74-76) mengatakan bahwa konten di dalam tradisi lokal biasanya mengandung sebuah glorifikasi terhadap raja-raja atau raja tertentu atau mungkin juga tentang asal-usul kerajaan tertentu. Beberapa karya Melayu klasik yang disebutkan oleh Djajadiningrat sebagai contoh adalah Hikajat Radja-Radja Pasai dan Hikayat Aceh. Selain dalam karya Melayu klasik, unsur glorifikasi juga ditemukan di dalam penulisan sejarah kerajaan Jawa. Sudibyo (2000:195) menyebutkan tiga naskah kanon yang menjadi sumber penulisan historiografi dinasti Jawa yang mengandung unsur glorifikasi, yakni Nagarakrtagama (Robson, 1994), Pararaton (Brandes, 1920), dan Babad Tanah Jawi (Meinsma, 1941).

\section{METODE PENELITIAN}

Objek material dalam penelitian ini ialah teks $H B$. Teks $H B$ yang dipilih adalah teks $H B$ Resensi I hasil suntingan J.J. Ras dalam disertasinya yang berjudul Hikajat Bandjar: A Study in Malay Historiography (1967). Pemilihan hasil suntingan J.J. Ras ini dilakukan dengan alasan dapat dipertanggungjawabkan. Objek formal yang ditentukan dalam penelitian ini yakni pola formula glorifikasi pemimpin yang terdapat di dalam cerita $H B$.

Pengumpulan data yang dilakukan pada penelitian ini adalah dengan metode kajian pustaka terhadap $H B$ untuk menemukan data-data yang berkaitan dengan objek formal. Pengumpulan data dilakukan dalam dua langkah. Langkah pertama ialah membaca $H B$ secara intensif dan kritis. Langkah kedua mengumpulkan data yang dibutuhkan dalam penelitian ini. Data yang dibutuhkan dalam penelitian ini adalah data mengenai tokoh pemimpin di dalam $H B$ serta porsi penceritaannya di dalam $H B$. Hal ini disebabkan terdapat 34 tokoh pemimpin yang disebutkan di dalam $H B$ tetapi hanya 19 tokoh pemimpin yang diceritakan secara lebih detail. 
Setelah data yang dibutuhkan di dalam objek material telah dikumpulkan, dilakukan analisis data dengan menggunakan metode struktur tokoh yang dilanjutkan dengan menggunakan metode formula kelisanan. Hal ini dilakukan karena penelitian ini memerlukan dua metode untuk mendapatkan hasil yang memadai. Oleh karena itu, analisis karya sastra dengan pendekatan struktural perlu dilakukan. Akan tetapi, analisis ini hanya dibatasi pada unsur tokoh karena tokoh merupakan aspek sentral dalam struktur naratif yang memiliki relasi dan fungsi pada unsur struktur karya sastra lainnya, seperti latar dan alur.

Setelah mendapatkan data tekstual mengenai unsur tokoh pemimpin yang ada di dalam $H B$, metode selanjutnya adalah mencari bukti adanya penggunaan formula di dalam narasi tokoh $H B$ sehingga analisis pola formula kelisanan dapat dilakukan dengan menggunakan metode Milman Parry dan Albert B. Lord. Akan tetapi, metode ini tidak dapat diterapkan secara keseluruhan di penelitian ini karena perbedaan jenis objek material yang digunakan. Milman Parry dan Albert B. Lord meneliti pergeseran yang terjadi dalam perulangan penyampaian sebuah epos berbentuk lagu di depan penikmat yang berbeda-beda, sedangkan penelitian ini mendasarkan diri pada naskah prosa panjang yang berasal dari sastra lisan yang ditulis oleh lebih dari dua penulis dengan kondisi yang berbeda-beda. Oleh karena itu, pengertian formula di sini ditafsirkan secara longgar sebagai kaidah yang memudahkan penyair membentuk pola penceritaan yang menjadi teknik pembangunan cerita.

Formula merupakan ide dasar dari kumpulan epitet, epos klise, dan frase-frase steretoip yang menjadi gawai mnemonik yang cocok dengan pola matriks tertentu dan membantu penyair dalam menggubahnya. Frase-frase tersebut dapat diganti atau diadaptasi dan berperan sebagai placeholder. Penyair menggubah sastra lisan dengan mengambil dariyang disebut oleh Lord sebagai-sebuah gudang yang memiliki banyak simpanan pola-pola tradisional (stock of trade) yang siap pakai dan digunakan dengan baik dalam pembentukan frase. Penyair menggunakan simpanan verba dan formula untuk mendeskripsikan tempat, mengekspesikan karakter yang berbeda-beda, dan menarasikan tingkah laku. Dengan begitu, penyair dapat menampilkan epos yang terdiri atas 10.000 kalimat atau lebih dengan fasih di depan pendengarnya.

Naskah $H B$ memiliki kaitan erat dalam tradisi penyampaian cerita lisan masyarakat Banjar sehingga kaidah penceritaannya masih berkaitan dengan teknik penyajian secara lisan. Oleh karena itu, yang terlebih dahulu dilakukan ialah membuktikan ciri-ciri penggunaan formula dan ekspresi formulaik dalam pembentukan citra pemimpin di dalam teks $H B$ yang 
terdapat secara dominan di dalamnya. Setelah ditemukan bukti-bukti penggunaan formula, metode yang dilakukan selanjutnya adalah menganalisis formula dan ekspresi formulaik yang membentuk glorifikasi pemimpin dalam $H B$.

\section{PEMBAHASAN}

\section{Formula Glorifikasi Pemimpin Dalam Hikayat Banjar}

Dalam pengertian luas, formula adalah sebuah struktur naratif atau kaidah dramatis yang digunakan dengan jumlah yang besar dalam karya-karya individual. Formula merupakan sebuah kombinasi atau perpaduan sejumlah kaidah kebudayaan tertentu dengan pola cerita yang lebih universal (Cawelti, 1976: 5-6). Secara lebih sempit, Milman Parry dan Albert Lord memberikan definisi formula sebagai sekelompok kata yang secara teratur dimanfaatkan dalam kondisi matra yang sama untuk mengungkapkan suatu ide yang hakiki. Analisis struktur cerita $H B$ bertolak dari teori formula yang dikemukakan oleh Lord dan Milman Parry. Akan tetapi, tidak keseluruhan metode tersebut dapat diterapkan dalam makalah ini. Hal ini disebabkan Lord meneliti mengenai pergeseran-pergeseran yang terjadi dalam perulangan penyampaian sebuah epos di depan penikmat yang berbeda-beda, sedangkan penelitian ini mendasarkan diri pada naskah prosa (Abdullah, 1991:522). Oleh karena itu, pengertian formula di sini ditafsirkan secara longgar sebagai kaidah yang memudahkan narator membentuk pola penceritaan yang menjadi teknik pembangunan cerita. Dalam hal ini dibatasi pada unsur-unsur glorifikasi yang dipandang dominan kedudukannya sebagai unsur pembangun cerita.

\section{Formula Dalam Struktur Sintaksis}

Satuan arti yang menentukan struktur formal linguistik karya sastra adalah kata (Pradopo, 2012:48). Menurut Aminuddin (1995:79), karya sastra merupakan bentuk komunikasi yang tidak dapat meninggalkan kata sebagai wahana ekspresi. Pengarang mempergunakan berbagai cara untuk dapat menjelmakan pikirannya dan pengalaman jiwanya ke dalam kata. Oleh karena itu, untuk menciptakan suatu karya, pengarang perlu menata sistem kebahasaan dengan gaya-gaya retoris tertentu sebagai media penyampaiannya. Penggunaan gaya-gaya retoris ditemukan di dalam $H B$ dan digunakan dalam jumlah yang cukup dominan sehingga membentuk suatu pola yang digunakan narator dalam penceritaan $H B$. 


\subsubsection{Enumerasi}

Enumerasi merupakan sarana retorika yang berupa pemecahan suatu hal atau keadaan menjadi beberapa bagian dengan tujuan agar hal atau keadaan itu lebih jelas dan nyata bagi pembaca atau pendengar (Pradopo, 2012:96). Enumerasi bertujuan untuk menguatkan suatu pernyataan atau keadaan dan memberi intensitas. Enumerasi bertujuan untuk menguatkan suatu pernyataan atau keadaan dan memberi intensitas seperti terlihat dalam kutipan berikut.

Kamudian daripada itu sudah barlayar anakoda Lampung itu mambawa sagala harta yang tinggal itu dangan orang banyak itu, kira-kira orang ampat ribu, parahu ampat puluh, ada pargata, ada pilang, ada gali, ada galiung, ada gurap, ada galiut, ada pilau, ada som, ada wangkang, ada kapal, saparti orang manyarang mangalahkan nagri rupanya itu, barlayar siang dan malam (Ras, 1968:252)

Pada kutipan di atas, pangkal keadaan yang dijelaskan adalah pelayaran anakoda Lampung yang membawa harta dan orang yang banyak. Hal ini kemudian dijelaskan dengan lebih terperinci lagi yakni orang banyak itu sekitar empat ribu orang, empat puluh perahu beserta jenis-jenis perahunya, diikuti perumpamaan di akhir deskripsi mengenai keadaan yang terjadi seperti orang menyerang sebuah negeri. Dalam $H B$, enumerasi sering dipadukan dengan repetisi verba seperti ada, mambawa, nomina seperti artinya, kimka, dan penyebutan angka dan warna.

Dalam $H B$, enumerasi merupakan gaya yang dominan ditemukan terutama pada $H B$ bagian pertama. Deskripsi dengan enumerasi digunakan untuk narasi deskripsi pakaian raja, penyerahan upeti, hadiah, atau seserahan untuk pernikahan raja, pesta resmi kerajaan, ungkapan kesedihan yang akan dijelaskan dalam subbab-subbab. Semua deskripsi tersebut kemudian menjadi pola cerita yang digunakan oleh narator sehingga perulangan adegan atau deskripsi siap dipakai. Fungsi enumerasi di dalam $H B$ terlihat jelas untuk pendeskripsian mengenai kehebatan dan kekayaan yang dimiliki oleh raja atau kerajaan.

\subsubsection{Deskripsi Pakaian Raja}

Deskripsi pakaian raja di dalam $H B$ menggunakan gaya retorika enumerasi. Hal ini terlihat jelas memiliki tujuan menggambarkan kemewahan, kekayaan, dan mempertegas status raja tersebut. Pendeskripsian pakaian raja selalu dihiasi dengan permata dan emas serta dengan warna-warna mencolok seperti jingga dan kuning. Deskripsi ini diikuti pula deskripsi mengenai dayang atau pengikut raja seperti kutipan mengenai deskripsi Empu Jatmika berikut ini. 
Maharaja itu barkain jingga barsulam dangan amas bartatah jumantan, barsabuk garingsing bartatah amas, barkaris carita bartatah sarip, panduknya timbaga suasa, landean amas mangawasari barparimata intan yang merah, pamandak basi bartatah jagasatru, warangka angsana diparamas, payung bawat dua sama bartulis air amas barbongkol mutiara, payung agung ampat, artinya payung ubur-ubur barsulam air amas, awinan sumpitan ampat barhurung-hurung amas, awinan tumbak barsulam suluh, awinan barhulas kimka kuning ampat, kimka merah ampat, kimka putih ampat, kimka hijau ampat, kimka hitam ampat, awinan astenggar sapuluh, panah ampat, dadap ampat, parisai sarta padangnya sapuluh, kolim sarta padangnya sapuluh, orang barbaju rantai sapuluh sabalah dan tameng Bali sarta padangnya bakupiah taranggos sachlat merah (Ras, 1968: 248-250).

Pada kutipan tersebut, dideskripsikan mengenai detail pakaian yang dikenakan oleh Empu Jatmika serta perhiasan-perhiasannya yang berupa sabuk garingsing yang dihiasi emas, keris carita dengan filigrana/filigri, tembaga, emas, dan intan permata. Deskripsi dengan enumerasi ini menggambarkan kemewahan pakaian dan perhiasan yang menjadi simbol status raja. Supit (2014:35) menyatakan bahwa ketika strata sosial di nusantara menjadi semakin komplek dengan terbentuknya kerajaan-kerajaan, fungsi perhiasan yang semula hanyalah sarana ekspresi diri dan penanda strata sosial menjadi tanda yang menunjukkan kekuasaan atau mempertontonkan kekayaan. Contoh data lain mengenai deskripsi pakaian raja di dalam $H B$ ialah deskripsi pakaian Putri Junjung Buih seperti yang tampak pada kutipan berikut.

Maka Putri itu kaluar dari dalam buit itu. Rupanya gilang-gumilang, cahayanya saparti kumala, mamakai pakaiannya dari dalam air itu-bartapih sutra kuning, barkakamban sutra kuning-dan bartudung kain kuning parbuatan anak dara ampat puluh itu (Ras, 1968:276)

Kutipan tersebut menarasikan pakaian Putri Junjung Buih ketika dia baru keluar dari buih yang ditemukan oleh Lambu Mangkurat. Dari kutipan tersebut, nampak deskripsi dengan gaya enumerasi yang menarasikan kecantikan Putri Junjung Buih. Deskripsi tersebut dipadukan dengan gaya pleonasme yang menyatakan 'rupanya gilang-gumilang, cahayanya seperti kumala'. Kata gilang-gemilang dalam KBBI memiliki arti 'bercahaya terang sekali'. Dengan menekankan bahwa cahaya tersebut luar biasa sehingga diterangkan gagasan lain yang untuk memberikan imajinasi kepada pembaca mengenai cahaya Putri Junjung Buih yang diibaratkan batu kumala atau kemala. Meskipun dalam deskripsi tersebut tidak disebutkan sejumlah perhiasan seperti emas dan permata sebagai simbol raja, pernyataan mengenai rupa Putri Junjung Buih yang diibaratkan cahaya batu kemala mewakili kemewahan dan keanggunan Putri tersebut. Narator $H B$ secara tersirat menarasikan bahwa tanpa perhiasan dan simbol status yang seperti dikenakan oleh raja-raja lain dalam $H B$, Putri Junjung Buih 
memiliki pesona yang lebih luar biasa yang menekankan bahwa Putri Junjung Buih adalah raja dengan membandingkan rupanya sama seperti perhiasan.

Meskipun gaya enumerasi sering kali dipakai untuk deskripsi pakaian raja, ciri ini hanya ditemukan pada $H B$ bagian pertama dan sangat jarang ditemukan pada $H B$ bagian kedua. Ras (1968: 160 - 169) berpendapat bahwa penulis $H B$ bagian kedua tidak mengikuti pola yang menjadi acuan penulis $H B$ bagian pertama. Ras mengatakan bahwa penulis yang melanjutkan penulisan $H B$ menggubah bagian yang ia tulis dengan gayanya sendiri. Oleh karena itu, enumerasi sangat sedikit ditemukan di dalam $H B$ bagian kedua. Deskripsi pakaian raja pada $H B$ bagian kedua dipersingkat narasinya sehingga sangat berbeda dengan deskripsi pakaian raja pada $H B$ bagian pertama.

\title{
1.1.2 Penyerahan Upeti dan Pemberian Hadiah
}

Seperti halnya gaya enumerasi yang digunakan pada deskripsi pakaian raja, gaya enumerasi digunakan pada narasi penyerahan upeti ataupun pemberian hadiah raja terhadap bawahannya ataupun kepada raja negeri lain. Gaya enumerasi pada penyerahan upeti atau hadiah ini tidak hanya menerangkan mengenai kekayaan kerajaan tetapi juga secara implisit menggambarkan kemurahhatian dan kedermawanan raja ataupun sebagai perasaan tunduk pada kerajaan superior di dalam narasi. Contoh data enumerasi yang diaplikasikan untuk penyerahan upeti adalah sebagai berikut.

\begin{abstract}
Maka Wiramartas disuruh pada raja Cina, mambawa intan sapuluh, mambawa mutiara ampat puluh, mambawa jumantan ampat puluh, mambawa polam ampat puluh, mambawa mirah ampat puluh, mambawa biduri ampat puluh dan lilin ampat puluh pikul dan damar saribu kindai, pekat saribu galung dan air madu saratus gantang, orang hutan sapuluh ekor, sarta mambawa surat maminjam orang yang tahu barbuat barhala gangsa. Sudah itu Wiramartas diparsalin sapanjanang badju sachlat, sabuk cindai, kain sarasah, karis balandean amas sarta sangunya. Yang mahiringkan, orang lima puluh, sama diparsalin sabuk kimka dan kain Kaling (Ras, 1968:254-256).
\end{abstract}

Pada kutipan tersebut dinarasikan bahwa Wiramartas pergi menghadap Raja Cina dengan membawa hadiah berupa batu dan barang berharga dalam jumlah yang cukup besar sebagai permintaan pembuat berhala. Hadiah tersebut dapat disamakan sebagai harga tawar untuk mempekerjakan pembuat berhala di Kerajaan Nagara Dipa. Deskripsi tersebut disertai pula bekal—sangu-Wiramartas yang berupa pakaian dan perhiasannya yang diberikan oleh raja kepada bawahannya. Contoh lain mengenai penggunaan enumerasi pada penyerahan 
hadiah adalah bagian cerita Lambu Mangkurat meminta Raden Suryanata sebagai suami Putri Junjung Buih berikut.

Sahutnya Lambu Mangkurat, "Hamba mahadap tuanku hamba mamuhunkan anak tuanku akan suami raja hamba itu, parampuan balum barsuami. Ini parsambahan hamba, intan sapuluh, mutiara sapuluh, mirah sapuluh, biduri sapuluh, zabarjat sapuluh dangan lilin sapuluh pikul, pekat saribu galung, tikar saratus kodi, tinggalung sapuluh, hayam sabungan sapuluh. Tiada dua-dua hamba puhunkan anak tuan hamba itu (Ras, 1968:304)."

Dapat dikatakan bahwa yang menjadi pangkal adalah persembahan yang kemudian dijabarkan berupa intan, mutiara, mirah, biduri, zabarjat masing-masing sepuluh, lilin sepuluh pikul, pekat seribu galung, tikar seratus kodi, tinggalung sepuluh, serta ayam sabungan sepuluh ekor. Pengulangan kata sepuluh pada kutipan tersebut merupakan repetisi untuk menyatakan jumlah setiap hadiah yang dipersembahkan. Oleh karena itu, kutipan di atas merupakan salah satu contoh perpaduan gaya enumerasi dengan repetisi angka yang menjadi salah satu pola di dalam $H B$. Persembahan yang dideskripsikan merupakan salah satu bentuk tunduknya Lambu Mangkurat kepada raja yang menerima persembahan tersebut, yakni raja Majapahit. Gaya enumerasi dalam deskripsi pemberian hadiah ini dapat ditemukan pada $H B$ bagian pertama dan $H B$ bagian kedua. Akan tetapi, deskripsi pada $H B$ bagian kedua tidak sepanjang dan seperinci deskripsi yang ada di $H B$ bagian pertama. Berikut kutipan pembanding dari $H B$ bagian kedua.

Kamudian daripada itu datang raja Sambas maaturkan intan dua biji, sarta ada barang lain-lain yang ada di Sambas itu diaturkannya tatapi yang tarsabutkan intan dua biji itu. Yang satu ada rigat sadikit, basarnya saparti buah tanjung, dinamai si Giwang. Satu basarnya saparti talur burung dara, itu dinamai si Misim (Ras, 1968:480).

Pada kutipan tersebut, tampak bahwa Raja Sambas menyerahkan upeti lain yang berupa barang lain-lain yang ada di Sambas. Akan tetapi, yang dinarasikan lebih lanjut hanya intan si Giwang dan si Misim yang menjadi hadiah utama Raja Sambas yang menjadi perhatian utama narator $H B$ bagian kedua. Penyebutan intan ini menjadi sesuatu hal yang tidak biasa di dalam $H B$ karena penamaan intan ini tidak ditemukan di narasi-narasi sebelumnya maupun sesudahnya. Penamaan benda-benda yang dinarasikan di dalam $H B$ bagian pertama hanyalah penamaan terhadap benda-benda pusaka yang dianggap keramat dan secara repetitif diulang di narasi mengenai raja-raja penerusnya seperti kapal Prabayaksa, keris Jaka Piturun, gamelan Rarasati, dan gong Rabut Paradah. Sedangkan intan Misim disebutkan kembali hanya di dalam satu narasi lain yang mengisahkan Marhum Panambahan 
mengutus Pangeran Ratu memberikan hadiah ke Mataram seperti yang tampak pada kutipan berikut.

Syahdan lagi kamudian daripada itu maka tarsabutlah Marhum Panambahan manyuruhkan Pangeran Dipati Tapasana, mangutus ka Mataram-akan mantri yang mahiringkan itu Kyai Tumanggung Raksanagara dan Kyai Narangbaya sarta orang mahiringkan itu dua ratusmaaturkan intan yang barnama si Misim itu sarta lawan sahang, pekat, tatudung, lilin itu (Ras, 1968:482).

Pada kutipan tersebut, penjabaran upeti tidak seperinci deskripsi pada $H B$ bagian pertama dengan hanya menyebut barang-barang yang diserahkan. Oleh karena itu, dapat dikatakan bahwa penggunaan enumerasi pada deskripsi pakaian di $H B$ bagian kedua sangat minim untuk mendeskripsikan pemberian hadiah atau penyerahan upeti.

\subsubsection{Pesta Resmi Kerajaan dan Upacara Kerajaan}

Enumerasi ditemukan pada pesta resmi kerajaan seperti pernikahan raja, kelahiran anak raja, naik tahta raja, serta upacara kerajaan. Enumerasi pada bagian ini digunakan untuk menggambarkan kemewahan pesta atau upacara, barang-barang dan perhiasan yang ditampilkan selama pesta atau upacara. Deskripsi mengenai proses berlangsungnya upacara seperti dua kutipan mengenai upacara Sabtu pada masa Empu Jatmika berikut.

Sudah jadilah sakaliannya astilah tahta karajaan itu tiap-tiap hari Sabtu maharaja Nagara Dipa itu dihadap sagala mantri di balairung - artinya di sitilohor-sarta dayang-dayang-artinya parakan jaba-sarta parhiasannya orang ampat puluh sama barsamir diparamas barumbai-rumbaikan ratna mutu manikam, mambawa lampit amas, mambawa kandaga amas bartatahkan intan dan biduri, dan wadah sirih dan wadah kapur-itu amas bartatahkan jambrut dan zabarjat-dan wadah timbako-sawung galing amas bartatah dangan kumala-hudutannya amas barcupak mirah (Ras, 1968:248).

Pada kutipan di atas diterangkan mengenai upacara Sabtu yang secara rutin dilakukan di Kerajaan Nagara Dipa. Hal-hal yang membangun upacara juga dijelaskan dalam kutipan tersebut, yakni upacara diadakan di balairung, ada dayang-dayang dan pesuruh yang masingmasing memakai selendang emas dan batu mulia. Seluruh sajian pun berupa tikar emas, peti emas dengan hiasan intan dan biduri, tempat sirih, kapur dan tembakau yang terbuat dari emas serta Selain itu, eEnumerasi juga digunakan untuk menggambarkan cara berlangsungnya upacara yang disebutan pada kutipan berikut.

Dan upacara dipasang pada rancak suji, saparti umbul-umbul dan panji-panji dan tatunggul dan lalayu dan kakalabangan dan kakenda sarta tumbak barkumbala putih dua puluh. Dan di hadapan rancak suji itu hindi dipegang ampat puluh sarta kantarnya, sarta mariam ampat pucuk itu disulat 
akan tanda raja itu kombali di pagungan. Rantaka disulat ampat kali tanda raja itu handak kaluar itu mambari ingat pada sagala yang seba itu sarta barbunyi gamalan mangasakar. Tatkala ka paseban dibunyikan orang galaganjur; jaka raja kombali damikian jua itu .... Sakaliannya tata parhiasan upicara alat itu bartata di hadapan raja (Ras, 1968:250).

Pada kutipan tersebut enumerasi dipadukan dengan gaya repetisi kata dan dan empat untuk menyatakan jumlah meskipun jumlah yang disebutkan bervariasi yakni empat dan empat puluh. Selain itu, deskripsi mengenai hiburan yang disajikan selama pesta atau upacara juga menggunakan gaya enumerasi. Abdullah (1991:553) menyebutkan bahwa gaya enumerasi ini digunakan berulang kali oleh narator apabila ia melukiskan suatu hal yang beraneka jenisnya. Selain itu, penggunaan gaya enumerasi menjabarkan kemeriahan yang terjadi pada saat pesta berlangsung. Salah satu pesta yang cukup meriah yakni saat Raden Suryanata datang ke Kerajaan Nagara Dipa dan diputuskan sebagai raja berikutnya. Saat itu digambarkan pesta berlangsung selama empat puluh hari empat puluh malam, dihadiri berbagai orang dari wilayah yang takluk kepada Kerajaan Nagara Dipa. Pesta tersebut dimeriahkan dengan acara menari, wayang, topeng, pertunjukan rakit, dan pertandingan gulat.

\begin{abstract}
Maka orang piadak ampat puluh hari ampat puluh alam, makan dan minum. Sagala sakai sama datang, orang Batang Tabalong, Batang Barito, orang Batang Alai, orang Batang Hamandit, orang Batang Balangan dan Batang Petak, orang Batang Biaju Kacil, orang Batang Biaju basar, dan orang Sabangau, orang Mandawai sarta orang Katingan, orang Sampit sarta orang takluknya, orang Pambuang sarta orang takluknya, sakaliannya itu datang dangan parsambahannya. Suka ramai piadak itu, ada barwayang di dalam, di pagungan orang barwayang wong, di paseban orang manopeng, di sitilohor orang marakit, di bawah panca parsada-artinya di bawah padudusanorang baokol. Lamun malam di dalam orang barjajogetan, ada baksa panah, ada baksa tumbak, ada baksa dadap, ada baksa hupak, ada baksa tameng, ada baksa bantar, ada bahigal radap (Ras, 1968:314).
\end{abstract}

Satu hal yang mencolok dari enumerasi dalam penggambaran pesta atau upacara kerajaan ini juga digunakannya pembanding antara upacara raja ahli waris dengan upacara pretender (raja yang naik tahta dengan cara merebut kekuasaan raja resmi). Dalam hal ini, enumerasi untuk menggambarkan kondisi pretender berfungsi sebagai sebuah kesialan atau juga tulah bagi pretender yang digambarkan oleh narator di dalam $H B$ seperti yang tampak pada kutipan mengenai upacara naik tahta Maharaja Mangkubumi berikut.

Maka Pangeran Mangkubumi itu sudah mamakai parhiasan astilah karajaan sarta upicara saparti adat dahulu kala, maka mangkota karajaan yang jatuh dari udara itu handak dipakai, tatkala handak dibawa ka padudusan dikanakan pada sirah Pangeran Mangkubumi, sasak sarta barat mangkota itu, tiada kuawa manjunjung Pangeran Mangkubumi pada mangkota itu, tiada baroleh bargarak gulunya itu, tiada jadi mamakai mangkota itu .... Maka heranlah Aria Taranggana sarta sakaliannya orang yang malihat itu, karana mangkota itu tahu barbasar, tahu barkacil, tahu babarat, tahu baringan .... sudah didudus Pangeran Mangkubumi itu maka badil yang dibawa oleh Maharaja Suryanata dari Majapahit itu disulat, dua tiga kali buntat itu, tiada mau barbunyi. 
Si Rabut Paradah ditabuh galaganjur tiada nyaring bunyinya. Si Rarasati ditabuh rarancakan tiada nyaring bunyinya (Ras, 1968:386-388).

Pada kutipan tersebut tampak bahwa raja tidak mampu memakai mahkota tersebut. Penjelasan sebelumnya merupakan penjabaran bagaimana kondisi mahkota tersebut selama upacara penobatan berlangsung, yakni raja tidak mampu memakai mahkota di kepalanya karena berat dan sesak, dan lehernya tidak dapat bergerak.

\subsubsection{Ungkapan Kesedihan}

Ungkapan kesedihan yang digambarkan di dalam $H B$ adalah ungkapan kesedihan ketika raja yang dinarasikan meninggal. Ungkapan kesedihan di dalam $H B$ bagian pertama sering kali menggunakan gaya enumerasi sebagai deskripsi sekaligus berfungsi sebagai pembuktian bahwa raja sangat disayangi oleh keluarga dan rakyatnya. Salah satu data ungkapan kesedihan mengenai meninggalnya raja seperti yang tampak pada kutipan berikut.

Sudah itu Empu Jatmika itu mati. Maka sagala mantri dan sakalian kulawarganya itu, dahulu anak-anak istrinya itu, sama manangis. Ada yang malulur-lulur kaki, ada yang barbadung-badung dadanya, ada yang mamukul-mukul kapalanya, ada yang barguling-guling di tanah. Banyaklah lakunya yang manangis itu, di dalam rumahnya dan pada pasebannya itu, bunyi gamuruh itu (Ras, 1968:268).

Pada kutipan tersebut tampak pangkal dari peristiwa yaitu kesedihan yang digambarkan secara tersirat melalui perincian kelakuan berduka orang-orang yang dinarasikan. Terlihat bahwa selain menangis, orang-orang juga mengelus-elus kaki, memukulmukul dada dan kepala, berguling-guling di lantai, serta beberapa kelakuan lain yang tampak pada ungkapan kesedihan lain di narasi mengenai kematian raja yang lain. Gaya enumerasi ini sering kali dipadukan dengan gaya paralelisme.

\subsubsection{Titah Raja}

Sebagai naskah genealogi, $H B$ memiliki banyak narasi mengenai titah raja. Akan tetapi, terdapat beberapa kondisi ketika titah raja tersebut menggunakan gaya retoris enumerasi yakni ketika raja menurunkan wasiat sebelum meninggal dunia atau pesan mengenai aturan kerajaan. Seringkali gaya retorika ini dipadukan dengan beberapa gaya lain seperti paralelisme, repetisi, dan pleonasme. Salah satu data mengenai hal ini terdapat pada kutipan berikut. 
Kata raja, "Hai sagala orang nagri Nagara Dipa, jangan lagi angkau sakaliannya itu mamakai saparti pakaian orang Malayu, atawa pakaian orang Walanda, atawa pakaian orang Cina, atawa pakaian orang Siam, atawa orang Acih, atawa orang Mangkasar, atawa pakaian cara Bugis. Sakaliannya itu jangan diturut, maski pakaian cara adat kita lagi di nagri Kaling itupun jangan lagi diturut karana kita sudah barlain nagri. Sudah kita barbuat nagri sandiri, manurut tahta astilah cara nagri Majapahit. Maka pakaian kita samuanya pakaian cara orang Jawa. Maka khabar carita orang tuha-tuha dahulu kala, manakala orang nagri itu manurut pakaian orang nagri lain niscaya datanglah sangsara pada nagri yang manurut pakaian orang nagri lain itu. Artinya sangsara itu bala, artinya bala itu kajahatan di dalam nagri itu, atawa banyak orang sakit, atawa musim tiada manjadi, artinya musim timur saparti musim barat musim barat saparti musim timur, atawa banyak pitanah, atawa parentah raja tiada manjadi karana orang kacil mamakai sahawa-nafsunya itu. Salah satu datangnya panyakit nagri itu manjadikan nagri susah (Ras, 1968:264).

Pada kutipan tersebut, dijelaskan aturan raja kepada masyarakatnya mengenai cara berpakaian. Terdapat larangan mengenakan pakaian adat tertentu yang diterangkan dengan cara enumerasi. Pangkal yang disebutkan ialah cara berpakaian cara Jawa yang dijadikan panutan. Selain itu diterangkan pula mengenai kesengsaraan yang akan menimpa jika aturan tersebut tidak diikuti, yaitu kejahatan yang terjadi di dalam negeri, orang-orang yang terkena penyakit, musim yang tidak menentu, serta banyaknya tipu muslihat yang terjadi di negeri tersebut.

Adapun mengenai titah dan wasiat raja pada $H B$ bagian pertama memiliki narasi dan pesan yang kurang lebih sama yakni mempertahankan tradisi kerajaan seperti cara berpakaian dan tata pemerintahan. Oleh karena itu, perulangan narasi dengan menggunakan enumerasi ini membentuk repetisi adegan atau deskripsi yang menjadi subbab pada bab tiga. Salah satu pembuktian bahwa enumerasi yang sama juga digunakan dalam wasiat raja Suryanata tampak pada kutipan berikut.

\begin{abstract}
"Hai Lambu Mangkurat dan Suryaganggawangsa dan Suryawangsa, pasanku jangan ada orang mamakai manurut pakaian orang nagri lain saparti pakaian cara Walanda, saparti cara Kaling, saparti cara Biaju, saparti cara Mangkasar, saparti cara Bugis, sakaliannya pakaian cara Malayu itu jangan diturut itu. Manakala manurut pakaian nagri lain niscaya nagri yang manurut itu baroleh sangsara itu, artinya baroleh kajahatan, parentah manjadi haru-hara. Artinya kajahatan itu banyak panyakit, jaka tiada banyak orang garing banyak pitanah, makanan larang, karana manurut pakaian nagri lain itu. Karana adat kita ini adat Jawa nagri Majapahit, itu tampatku mula-mula ada (Ras, 1968:328)."
\end{abstract}

Penjabaran mengenai pakaian nagri lain diterangkan secara lebih lanjut dengan enumerasi yang dipadukan dengan repetisi frase saparti cara. Pada bagian lainnya, enumerasi kembali digunakan untuk menerangkan kesengsaraan yang akan terjadi apabila pesan raja tidak dilakukan. Kesengsaraan tersebut berupa kejahatan, munculnya penyakit, tipu muslihat, serta harga pangan yang mahal. Selain pada titah dan wasiat yang memiliki pesan yang sama 
di $H B$ bagian pertama, enumerasi juga digunakan pada titah raja pada $H B$ bagian kedua seperti pernyataan Sultan Suryanullah yang berhasil memenangkan perang saudara dengan Pangeran Tumanggung berikut.

Sudah kamudian daripada itu Pangeran Samudra itu barkata pada Pangeran Tumanggung itu: "Handak hilir. Tatapi Aria Taranggana kaula bawa, sarta sakalian orang dalam nagri Nagara-Daha ini. Adapun andika tinggal, sagala orang di dalam batang Hamandit, di dalam batang Alai ini kaula aturkan itu." .... Sudah itu maka Pangeran Samudra hilir itu, orang Nagara Daha itu habis dibawa. Hanya ditinggal akan tunggu nagri itu: basar kacil, laki-laki dan parampuan, orang saribu itu (Ras, 1968:438)

Pada kutipan di atas, dijelaskan bahwa Pangeran Samudra atau Sultan Suryanullah meninggalkan Pangeran Tumanggung dengan sekelompok orang di Batang Hamandit dan Batang Alai yang dirunut di deskripsi berikutnya yakni orang dewasa, kecil, laki-laki, dan perempuan dengan jumlah seribu. Enumerasi tidak diterangkan secara terperinci di dalam dialog raja akan tetapi dijelaskan kemudian di deskripsi cerita. Selain pada kutipan tersebut, penggunaan enumerasi untuk titah raja pada $H B$ bagian kedua sangat jarang ditemukan.

\subsubsection{Aset dan Kondisi Kerajaan}

Pembuktian mengenai kekayaan kerajaan dalam $H B$ dinyatakan dengan gaya enumerasi dalam mendeskripsikan pakaian raja, penyerahan upeti dan hadiah, serta narasi mengenai aset dan kondisi kerajaan. Sama seperti narasi bagian lain, $H B$ bagian pertama sangat kaya akan deskripsi dengan enumerasi untuk menarasikan aset kerajaan. Itu artinya, narator menggunakan enumerasi sebagai pola pembentuk cerita yang dianggap mampu menjelaskan bahwa kerajaan yang diceritakan, dalam hal ini Kerajaan Nagara Dipa dan Kerajaan Nagara Daha, sangat kaya dan makmur. Selain aset kerajaan, enumerasi juga digunakan untuk deskripsi kondisi kerajaan seperti di kutipan yang nampak di bawah ini.

\footnotetext{
Hatta barapa lamanya kamudian daripada itu makmur nagri Nagara Dipa itu bartambah-tambah makmur, suka ramai. Banyak orang barbaniaga, saparti Cina dan Malayu, orang Johor, orang Acih, orang Malaka, orang Maningkabau, orang Patani, orang Mangkasar, orang Bugis, orang Sumbawa, orang Bali, orang Jawa, orang Bantan, orang Palembang, orang Jambi, orang Tuban, orang Madura itu, orang Walanda, orang Makkau, orang Kaling. Ada yang satangahnya itu bardiam sakali, orang dagang-dagang itu (Ras, 1968:262).
}

Pada kutipan di atas diterangkan bahwa kemakmuran Negeri Nagara Dipa terjadi karena ramainya orang-orang luar yang datang untuk berdagang. Pada kutipan tersebut, enumerasi dipadukan dengan repetisi orang untuk menjabarkan pedagang-pedagang dari penjuru tempat yang berdatangan ke Nagara Dipa. Dapat dilihat di sini bahwa bertambah 
makmur dan suka ramai yang disebutkan di awal deskripsi yakni berupa suksesnya jalur perniagaan Kerajaan Nagara Dipa yang membuat pedagang dari berbagai tempat berdatangan bahkan mendiami Kerajaan Nagara Dipa. Contoh lain mengenai penggunaan enumerasi pada kondisi kerajaan tampat pada kutipan berikut ini.

Kamudian daripada itu maka astilah tahta karajaan raja Nagara Dipa itu tarmashur baik tahtanya karana manurut tahta astilah raja di Majapahit itu, manurut cara Jawa itu, sarta sagala pakaiannya itu manurut cara Jawa itu. Sudah sama ditinggalnya sagala tahta astilah pakaian di nagri Kaling itu oleh sagala orang nagri Nagara Dipa itu. Basar kacil, laki laki parampuan itu sama mamakai pakaian cara Jawa sakaliannya (Ras, 1968:262-264).

Pada kutipan tersebut, dapat diketahui bahwa Raja Nagara Dipa sangat termashur namanya. Kemashuran, menurut narator $H B$, ialah cara raja Nagara Dipa mengadopsi tata negara dan adat berpakaian Majapahit untuk mengatur Kerajaan Nagara Dipa. Penggunaan enumerasi pada bagian ini juga sering ditemukan pada $H B$ bagian kedua meskipun dalam hal ini narator untuk $H B$ bagian kedua sangat sedikit menarasikan kondisi kerajaan selain alur pernikahan dan keturunan raja. Berikut adalah penggunaan enumerasi yang ditemukan di dalam $H B$ bagian kedua untuk menarasikan kondisi kerajaan.

Karajaan Sultan Suryanullah tahta astilahnya sampurna saparti astihadat dahulu jua itu, saparti adat Jawa itu. Tiada maniru pakaian cara Mangkasar,tiada cara pakaian Bugis. Tiada dibarikan bartanam sahang labih daripada dua tiga tunggulnya saorang-saorang itu, hanya akan cagar dimakan. Lamun banyak, akan mancari harta itu, manjadikan sangsara nagri: saraba larang dan banyak pitanah datang, parentah tiada manjadi karna orang banyak barani kapada raja (Ras, 1968:442).

Pada kutipan di atas narasi mengenai kondisi kerajaan tidak jauh berbeda dari pesan wasiat atau titah raja pada bagian sebelumnya yang menyebutkan bahwa penduduk kerajaan tidak diperkenankan untuk meniru cara berpakaian adat lain selain Jawa. Dari hal ini dapat diketahui bahwa repetisi digunakan untuk perulangan adegan atau deskripsi yang akan diterangkan pada subbab mengenai teknik pengembangan cerita.

\subsection{Paralelisme}

Paralelisme (persejajaran) ialah mengulang isi kalimat yang maksud yang tujuannya serupa. Kalimat yang berikut hanya dalam satu atau dua kata berlainan dari kalimat yang mendahului (Pradopo, 2012:97). Paralelisme pada hakikatnya adalah suatu bentuk pengulangan struktur gramatikal atau pengulangan struktur bentuk (Nurgiyantoro, 2014:252). 
Penggunaan paralelisme bertujuan untuk menekankan dan mendukung gagasan yang sederajat yang dijelaskan di dalam teks.

Dalam $H B$, paralelisme juga digunakan sebagai salah satu sarana retorik narator dalam menarasikan pemimpin Banjar. Penggunaan paralelisme dengan bentuk perulangan kata sinonim tidak hanya terdapat pada keparalelan antarkalimat tetapi juga ditemukan di dalam kalimat. Salah satu contoh deksripsi dengan menggunakan paralelisme perulangan kata sinonim yang terdapat di dalam kalimat ialah dua kata bersinonim tinggal dan diam yang terdapat di dalam kutipan berikut.

Ki Mas Lalana pun bartinggal, bartiga dangan hambanya, didiamkan Lambu Mangkurat di rumah dalam pagar Lambu Mangkurat itu (Ras, 1968:362).

Contoh lain penggunaan paralelisme dengan perlawanan dalam tingkatan semantik terdapat pada kutipan berikut ini.

\footnotetext{
“Hai tuanku Lambu Mangkurat, tiada dua-dua hamba mamuhunkan ampun, dahulu-dahulunya ka bawah duli syah alam, kadua parkara ka bawah kadam tuanku Lambu Mangkurat. Daripada hamba sangat babal dan bingung tiada tahu akan pakarti tahta astilah diparhambakan raja. Maka sakarang ini tiada dua-dua ampun pangapura syah alam dangan tuanku Lambu Mangkurat hamba junjung siang dangan malam. Tiada kuasa manjunjung duli syah alam dangan duli tuanku Lambu Mangkurat, hanya nugraha pangapura ampun syah alam dangan tuanku Lambu Mangkurat yang hamba junjung atas batu kapala patik malam dan siang (Ras, 1968:342)."
}

Kutipan di atas merupakan dialog Aria Malingkun yang merasa hormat, takut, dan tunduk di bawah kuasa Lambu Mangkurat ketika Lambu Mangkurat meminta anak Aria Malingkun untuk dijadikan istri raja. Tampak bahwa tiga dari empat kalimat pada kutipan memiliki kesejajaran yakni berupa permintaan ampun. Mamuhunkan ampun pada kalimat pertama menjadi pangkal utama yang menyebabkan paralel di kalimat-kalimat selanjutnya terjadi. Pada kalimat ketiga, tiada dua-dua ampun menjadi penegasan kesungguhan dari mamuhunkan yang terdapat pada kalimat pertama. Frase mamuhunkan ampun dan tiada duadua ampun pada kalimat pertama dan ketiga merupakan pola repetisi yang berpusat pada pembicara, sedangkan nugraha pangapura ampun pada kalimat keempat merupakan perlawanan dari dua frase sebelumnya yang menjadikan lawan bicara sebagai pusat dari kalimat tersebut. Selain itu, kalimat keempat juga menandakan bahwa lawan bicara merupakan sosok yang berkuasa dan memiliki wewenang terlebih terhadap pemberian ampun terhadap pembicara. 
Paralelisme merupakan gaya retorik yang dominan ditemukan di dalam $H B$ bagian kedua. Terdapat beberapa variasi paralelisme di dalam $H B$ bagian kedua. Salah satunya adalah perulangan kata depan untuk oksimoron dalam paralelisme struktur kata seperti yang tampak pada kutipan berikut.

Dicari orang $\boldsymbol{k a}$ hulu $\boldsymbol{k a}$ hilir, $\boldsymbol{k a}$ darat $\boldsymbol{k a}$ laut, tiada dapat (Ras, 1968:466).

Penggunaan kata depan $k a$ untuk penanda arah menjadi bentuk paralelisme struktur kata. Dari hal ini dapat dilihat bahwa narator $H B$ bagian kedua memanfaatkan struktur paralelisme ini untuk penekanan gagasan yang sakral. Paralelisme dalam $H B$ bagian kedua lebih dominan digunakan di dalam kalimat. Hal itu berbeda dengan penggunaan $H B$ bagian pertama. paralelisma lebih sering ditemukan dalam jajaran kalimat.

\subsection{Repetisi}

Repetisi merupakan salah satu ciri utama yang membedakan puisi dengan prosa. Akan tetapi dalam $H B$, repetisi menjadi suatu gaya yang dominan ditemukan baik dalam struktur sintaksis hingga perulangan deskripsi. Repetisi menjadi suatu siasat narator $H B$ untuk membentuk teks sastra menjadi indah penuturannya. Gaya retoris repetisi memiliki fungsi untuk menekankan dan menegaskan sesuatu yang penting yang dinarasikan. Pengulangan yang terjadi berupa bentuk perulangan bunyi, kata, bentukan kata, frase, kalimat, hingga deskripsi.

Salah satu contoh repetisi dalam $H B$ yang mencolok dan dominan ditemukan adalah kalimat banyak yang tiada tarsabut. Kalimat tersebut memiliki arti bahwa selain apa yang dinarasikan, ada peristiwa serupa atau lainnya yang terjadi di antara peristiwa yang telah diceritakan dan peristiwa yang akan diceritakan tetapi tidak dinarasikan oleh narator. Hal ini memiliki fungsi lain untuk mengisi keganjilan yang terjadi jika suatu cerita mengalami loncatan waktu (time skip) yang jauh jaraknya dari peristiwa sebelumnya. Hal ini disebabkan dalam $H B$ tidak ada penanda khusus dalam memulai suatu peristiwa atau babak cerita. Salah satu contoh loncatan waktu yang mencolok di dalam $H B$ ialah peristiwa kepergian Raden Sari Kaburungan pada usia tujuh tahun. Untuk menghilangkan kejanggalan atau efek kejut terhadap pergantian peristiwa yang secara tiba-tiba, kalimat banyak tiada tarsabut digunakan untuk mempersingkat cerita yang terjadi di antaranya. Kalimat tersebut sering kali 
divariasikan oleh narator untuk meringkas suatu penjelasan. Perulangan kalimat tersebut dominan ditemukan di $H B$ bagian pertama dan $H B$ bagian kedua.

Perulangan juga terjadi pada kalimat lain tetapi hanya ditemukan pada $H B$ bagian pertama. Kalimat tersebut yakni itulah yang diturut oleh raja-raja sampai sakarang ini. Perulangan kalimat ini cukup penting untuk dibahas. Kalimat ini menjadi kalimat yang ditemukan di akhir deskripsi yang deskripsi tersebut diulang kembali di dalam narasi mengenai kehidupan raja-raja selanjutnya. Hal ini kemudian menjelaskan kalimat yang juga terus diulang di deskripsi lain di dalam narasi $H B$ yakni maka tahta karajaan saparti zaman dahulu jua itu. Kalimat tersebut digunakan untuk menjelaskan tata kerajaan serta tradisi adat yang dilakukan oleh raja yang berkuasa saat narasi dilakukan menggunakan deskripsi yang sama seperti deskripsi mengenai kondisi dan peristiwa yang terjadi pada masa kekuasaan sebelumnya atau lebih jauh lagi, sama seperti tata kerajaan ketika dinasti pertama berlangsung.

Repetisi yang digunakan dalam tataran sintaksis yang lebih sering ditemukan di dalam $H B$ bagian kedua hanya berupa perulangan kata dan frase. Hal ini berbeda dari repetisi yang terdapat pada $H B$ bagian pertama yang lebih sering menggunakan repetisi klausa dan kalimat. Kata dan frase yang paling sering diulang di dalam $H B$ bagian kedua adalah baristri, sudah itu, maambil anak, dikawini/mangawini, sumalah, baranak, bartinggal/tiada bartinggal, dan itu/masih ada. Perulangan itu tidak hanya pada kutipan di atas tetapi juga diulang pada seluruh babak cerita sultan-sultan Banjar yang lain.

\section{Formula Dalam Tekhnik Pengembangan Cerita: Perulangan Adegan atau Deskripsi}

Narator $H B$ menggunakan pola tertentu sebagai teknik untuk mengembangkan cerita $H B$. Pola yang sangat menonjol yang dapat ditemukan di dalam $H B$ ialah perulangan adegan atau deskripsi dan perulangan pengisahan. Pola ini merupakan pola yang dapat ditemukan di dalam $H B$ bagian pertama dan $H B$ bagian kedua, meskipun dalam hal formula struktur sintaksisnya, $H B$ pertama dan $H B$ kedua memiliki pola yang sangat berbeda. Perulangan adegan dan deskripsi ini terlihat menonjol dan dominan. Hal ini mengindikasikan bahwa narator memiliki sejumlah adegan siap pakai untuk mengembangkan cerita sesuai dengan kebutuhannya. Pada penjelasan mengenai enumerasi titah raja sebelumnya disebutkan bahwa titah dan wasiat raja sering kali memiliki kesamaan. Oleh karena itu, dalam hal perulangan 
adegan, perulangan yang terjadi tidak hanya dalam bentuk narasi akan tetapi juga bentuk dialog tokoh.

Sebagai naskah genealogi, unsur utama $H B$ ialah narasi kehidupan raja-raja yang pernah memimpin Kerajaan Nagara Dipa, Kerajaan Nagara Daha, dan Kesultanan Banjar. Oleh karena itu, dalam membangun cerita $H B$ narator memiliki teknik penceritaan yang berupa pola-pola untuk mengembangkan cerita serta sebagai stock of trade narator yang siap dipakai untuk membangun cerita mengenai fase kehidupan raja-raja di dalam $H B$.

Dalam $H B$, susunan peristiwa dalam penceritaan fase kehidupan raja-raja adalah sebagai berikut: (1) kelahiran raja, (2) raja naik tahta, (3) pernikahan raja, (4) raja memiliki keturunan, (4a) pernikahan anak raja, (4b) kematian anak raja, (5) raja wafat. Pola (2) dan (3) sering kali ditukar oleh narator tetapi untuk susunan peristiwa kehidupan raja di $H B$ kelima pola tersebut terus menerus digunakan oleh narator secara berurutan. Pola yang sama juga ditemukan di dalam $H B$ bagian kedua, akan tetapi sering kali narator $H B$ bagian kedua menggunakan urutan peristiwa (1), (3), (4, 4a, 4b), (2), (5).

Pada $H B$ bagian kedua, untuk adegan raja naik tahta dan selama ia berkuasa, terdapat pula adegan mengenai pemberian gelar baik kepada keluarga raja maupun kepada prajurit kerajaan yang dianggap telah menunaikan tugasnya dengan baik. Pemberian gelar ini tidak ditemukan di dalam $H B$ bagian pertama sehingga dapat dikatakan bahwa peristiwa ini adalah pola yang mulai ditulis ketika narator $H B$ kedua mengambil alih untuk melanjutkan cerita $H B$. Penyebutan tokoh yang telah diberikan gelar pada $H B$ bagian kedua pun kemudian menjadi tidak konsisten dan berubah-ubah mengikuti gelar yang diberikan sebelumnya.

\section{KESIMPULAN}

Karya sastra masa lalu menyimpan informasi dan sistem nilai yang secara langsung relevan untuk masyarakat tempat ia muncul. Untuk menyimpan informasi tersebut, penceritaannya dipermudah dengan membentuk ungkapan-ungkapan khas yang bersifat formulaik. Sebagai salah satu karya sastra masa lalu yang tumbuh dan berkembang di tengah masyarakat yang kaya dengan tradisi lisan, $H B$ memiliki kecenderungan besar memiliki jejak sastra lisan meskipun telah dialihkan menjadi sastra tulis pada masa Kesultanan Banjar. Sistem formula yang digunakan di dalam sastra lisan digunakan untuk menuliskan garis keturunan raja-raja dan sultan Banjar sebagai pemenuhan legitimasi bahwa raja dan 
keturunannya merupakan orang-orang yang memang diharuskan menguasai tahta kerajaan. Pengagungan terhadap sosok tunggal raja yang dipercaya sebagai keturunan dewa penguasa alam menjadi ciri khas yang dominan ditemukan di dalam $H B$.

\section{DAFTAR PUSTAKA}

Abdullah, I. T. (1991). Hikayat Meukuta Alam: Suntingan Teks dan Terjemahan Beserta Telaah Struktur dan Resepsinya. Intermasa.

Allen, R. E. (1990). The Concise Oxford Dictionary of Current English. Oxford University Press.

Aminuddin. (1995). Stilistika: Pengantar Memahami Bahasa dalam Karya Sastra. IKIP Semarang Press.

Bahasa, P. (2008). Kamus Besar Bahasa Indonesia Pusat Bahasa edisi Keempat. Gramedia Pustaka Utama.

Bondan, A. H. (1953). Suluh Sedjarah Kalimantan. Fajar.

Braginsky, V. I. (1998). Yang Indah, Berfaedah, dan Kamal: Sejarah Sastra Melayu dalam Abad 7-19. INIS.

Cawelti, J. G. (1976). Adventure, Mystery, and Romance: Formula Stories as Art and Popular Culture. The University of Chicago Press.

Djajadiningrat, H. (1965). Local Traditions and the Study of Indonesian History. In An Introduction to Indonesian Hostoriography (pp. 74-76). Cornell University.

Fairchild, H. P. (1962). Dictionary of Sociology and Related Sciences. Littlefield, Adams.

Fang, L. Y. (2011). Sejarah Kesusastraan Melayu Klasik. Yayasan Pustaka Obor Indonesia.

Faruk. (2014). Metode Penelitian Sastra: Sebuah Penjelajahan Awal. Pustaka Pelajar.

Hermawan, S. (2005). Kompleksitas Penggunaan Teks Sastra sebagai Sumber Kajian Sejarah Catatan dari Kajian Hikajat Bandjar J.J. Ras. Jurnal Wiramartas, 1(2), 66-135.

Jauss, H. R. (1982). Toward an Aesthetic of Reception. University of Minnesota Press.

Lord, A. B. (1971). The Singer of Tales. Atheneum.

Mu'jizah. (2004). Tempat-Tempat Perkembangan Sastra Melayu: Banjarmasin. In Sastra Melayu Lintas Daerah. Pusat Bahasa Departemen Pendidikan Nasional.

Noor, Y. (2016). Islamisasi Banjarmasin: Abad ke-15 sampai ke-19. Ombak.

Nurgiyantoro, B. (2014). Stilistika. Gadjah Mada University Press.

Pradopo, R. D. (2012). Pengkajian Puisi. Gadjah Mada University Press.

Ras, J. J. (1968). Hikajat Bandjar: A Study in Malay Historiography. Martinus Nijhoff.

Robson, S. O. (1994). Prinsip-Prinsip Filologi Indonesia. RUL.

Setiawan, I. (2014). Eksnominasi Politik Dalam Narasi: Konseptualisasi Pemikiran Mitologis Roland Barthes dan Implikasi Metodologisnya dalam Kajian Sastra. Jurnal Jentera 3, $23-35$.

Sudibyo. (2000). Mistifikasi Dan Pengagungan Kekuasaan Dalam Babad Dan Hikayat: Kontinuitasnya Dalam Sistem Kekuasaan Indonesia Modern. Humaniora, 12(2), 195204.

Supit, T. W. (2014). Kisah Perhiasan Nusantara (M. Nusantara (ed.)).

Sweeney, A. (1987). A Full Hearing: Orality and Literacy in the Malay World. University of California Press.

Teeuw, A. (1994). Indonesia Antara Kelisanan dan Keberaksaraan. Pustaka Jaya.

Turner, B. S. (2006). The Cambridge Dictionary of Sociology. Cambridge University Press. 